\title{
Frailty in Pulmonary and Critical Care Medicine
}

\author{
Jonathan P. Singer ${ }^{1}$, David J. Lederer ${ }^{2,3}$, and Matthew R. Baldwin ${ }^{4}$ \\ ${ }^{1}$ Department of Medicine, University of California San Francisco, San Francisco, California; ${ }^{2}$ Department of Medicine and ${ }^{3}$ Department \\ of Epidemiology, Columbia University Medical Center, New York, New York; and ${ }^{4}$ Department of Medicine, Columbia University \\ Medical Center, New York, New York
}

\begin{abstract}
Conceptualized first in the field of geriatrics, frailty is a syndrome characterized by a generalized vulnerability to stressors resulting from an accumulation of physiologic deficits across multiple interrelated systems. This accumulation of deficits results in poorer functional status and disability. Frailty is a "state of risk" for subsequent disproportionate declines in health status following new exposure to a physiologic stressor. Two predominant models have emerged to operationalize the measurement of frailty. The phenotype model defines frailty as a distinct clinical syndrome that includes conceptual domains such as strength, activity, wasting, and mobility. The cumulative deficit model defines frailty by enumerating the number of age-related things wrong with a person. The biological pathways driving frailty include chronic systemic inflammation, sarcopenia, and
\end{abstract}

neuroendocrine dysregulation, among others. In adults with chronic lung disease, frailty is independently associated with more frequent exacerbations of lung disease, all-cause hospitalization, declines in functional status, and all-cause mortality. In addition, frail adults who become critically ill are more likely develop chronic critical illness or severe disability and have higher in-hospital and long-term mortality rates. The evaluation of frailty appears to provide important prognostic information above and beyond routinely collected measures in adults with chronic lung disease and the critically ill. The study of frailty in these populations, however, requires multipronged efforts aimed at refining clinical assessments, understanding the mechanisms, and developing therapeutic interventions.

Keywords: frailty; body composition; disability; health-related quality of life; mortality

(Received in original form December 22, 2015; accepted in final form April 22, 2016)

Supported by NHLBI grant K23 HL 111115 (J.P.S.) and National Institute on Aging grant K23 AG045560 (M.R.B.).

Correspondence and requests for reprints should be addressed to Jonathan P. Singer, M.D., M.S., 350 Parnassus Avenue, Suite 609, San Francisco, CA 94117. E-mail: jon.singer@ucsf.edu

This article has an online supplement, which is accessible from this issue's table of contents at www.atsjournals.org

Ann Am Thorac Soc Vol 13, No 8, pp 1394-1404, Aug 2016

Copyright (C) 2016 by the American Thoracic Society

DOI: 10.1513/AnnalsATS.201512-833FR

Internet address: www.atsjournals.org

As early as the 1940s, geriatricians recognized subgroups of older adults whose functional limitations and age-related comorbid conditions appeared greater than could be expected by chronologic age alone (1). It was not until the early 21 st century, however, that this phenomenon was defined by investigators, including Linda Fried and Kenneth Rockwood, as a distinct syndrome they termed "frailty" $(2,3)$.

Today, the most commonly referenced definition considers frailty to be an accumulation of physiologic deficits across multiple interrelated systems that results in both concurrent functional limitations and vulnerability to new stressors (2). Frailty represents a "state of risk" in which a relatively small stressor that might have otherwise been inconsequential exceeds the now-diminished physiologic reserves, resulting in a disproportionate (and potentially catastrophic) decline in health status.

In the field of geriatrics, frailty is associated with those outcomes most important to older adults-namely, the loss of the physical and cognitive functioning needed to maintain an independent lifestyle. Indeed, frailty not only is associated with prevalent physical and cognitive impairments but also identifies patients at increased risk for falls, hospitalization, institutionalization, poorer health-related quality of life, and death (2-10).
Conceptually, in pulmonary medicine, frail patients with lung disease may be at heightened risk for pulmonary exacerbations and, if exacerbations occur, may be more likely to experience greater loss of functioning and death (Figure 1A). In critical care medicine, frail patients who develop acute critical illness may be more likely to experience early mortality or, if they survive to discharge, may require prolonged or permanent institutionalization (Figure 1B). Recently, frailty has been identified as a risk factor for poor outcomes in adults with lung disease and critical illness-including those of younger age $(6,7,11-17)$.

We review the pathobiology underpinning the frailty syndrome, a 
A

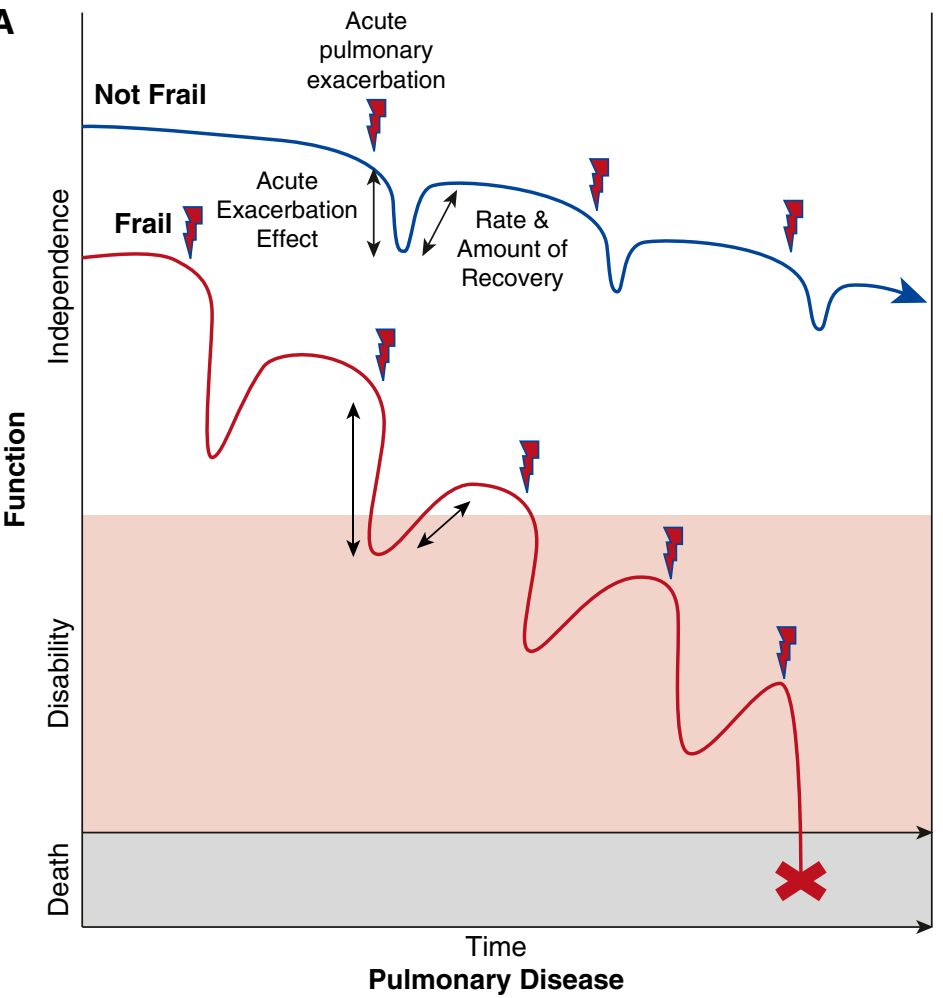

B

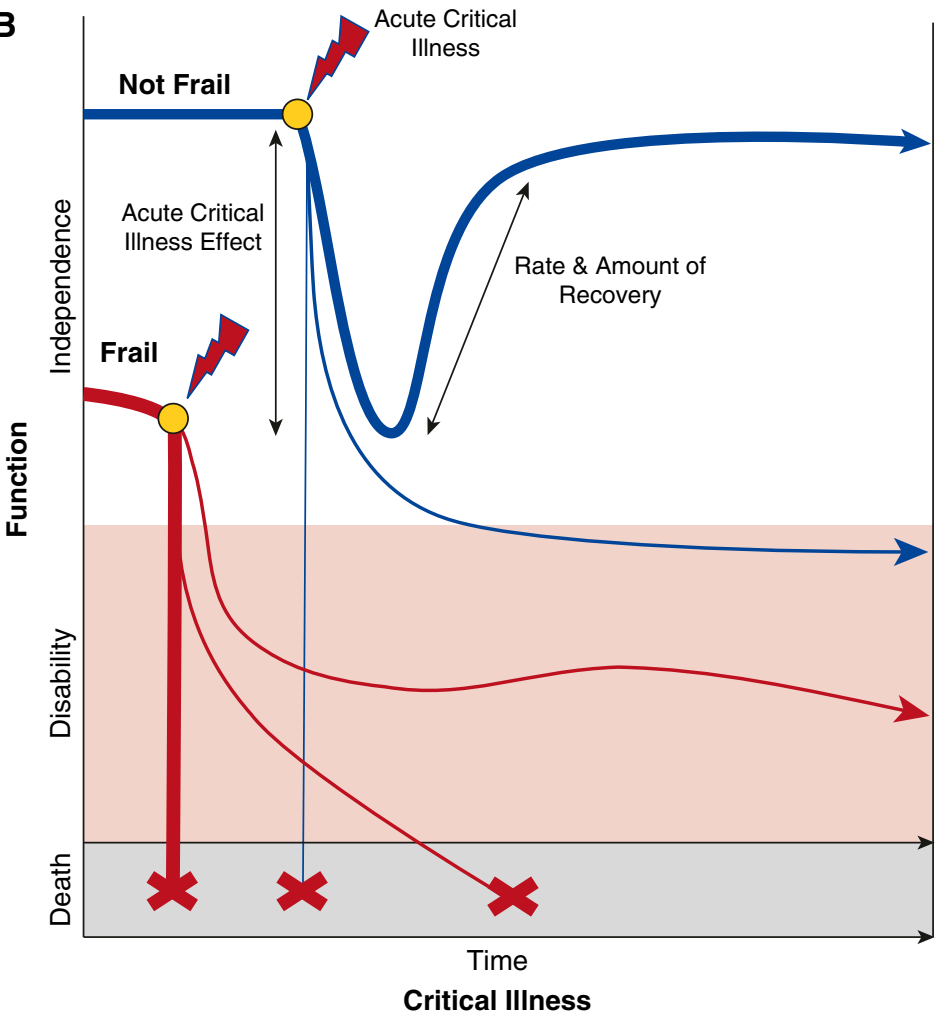

number of instruments used to operationalize frailty measurement, and the associations between frailty and health outcomes in adults with lung disease and critical illness.

\section{Pathobiology of Frailty}

The putative mechanisms underlying frailty are multiple and reflect the complexity of the aging process. Although a detailed discussion is beyond the scope of this review, we highlight some of the potential mechanisms that, either individually or more likely in combination, cause frailty.

López-Otín and colleagues proposed nine molecular and cellular hallmarks of aging, which are themselves affected by genetic, epigenetic, and environmental factors (Figure 2) (18). In addition to these nine hallmarks of aging (i.e., immune senescence, mitochondrial dysfunction, telomere attrition), other putative causes of frailty include physical inactivity, malnutrition, and age-related diseases (e.g., dementia, osteoporosis). Either individually or in combination, these factors are believed to result in pathobiological perturbations such as chronic inflammation, immune senescence, endocrine dysregulation, and muscle dysfunction and sarcopenia (19). Once frailty develops, a new physiologic stressor (e.g., acute exacerbation of chronic obstructive pulmonary disease [COPD] or critical illness) can exceed the available physiologic reserves, resulting in disability, morbidity, and death.

Chronic systemic inflammation is considered to be one of the primary pathobiological changes driving frailty (20). First described in community-dwelling older adults, frail adults had increased serum levels of the proinflammatory cytokine IL-6 compared with nonfrail adults (21). Since then, others have identified associations between frailty and biomarkers of inflammation, including IL-6, tumor necrosis factor (TNF)- $\alpha$, and C-reactive protein (22-27).

Because operational definitions of frailty involve deficits in functioning (i.e., slowness, weakness), abnormal muscle mass and function is also considered to be a fundamentally important cause of frailty (28). Sarcopenia is defined as abnormally low lean muscle mass combined with low
Figure 1. (A) Hypothetical trajectories of functional status for patients experiencing recurrent acute exacerbations of chronic lung disease who are frail (red line) and not frail (blue line). Frail patients are susceptible to more frequent exacerbations with less recovery in between, resulting in faster loss of functional status, earlier onset of disability, and a shorter lifespan. (B) Hypothetical trajectories for 


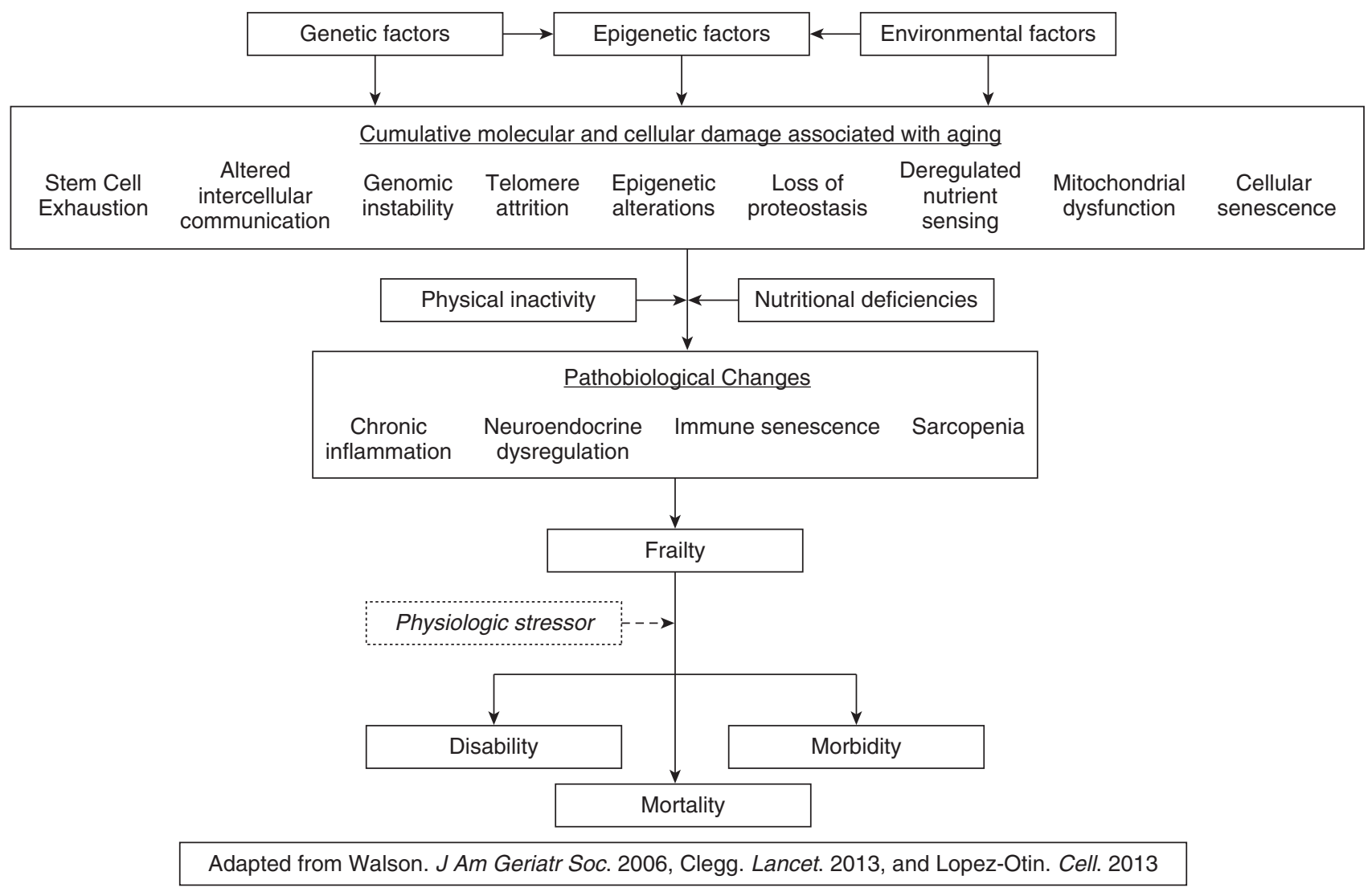

Figure 2. Hypothesized genetic, molecular, and functional changes underlying the frailty phenotype. Adapted by permission from References 18 , 19 , and 118.

muscle strength or function (29). The mechanisms by which sarcopenia develops include protein and micronutrient deficiencies, chronic inflammation, endocrine dysregulation, and disuse atrophy-all of which are also associated with frailty (30). Furthermore, certain biomarkers, such as IL- 6 and TNF- $\alpha$, directly induce muscle catabolism $(31,32)$.

Dysfunction in the endocrine axes affecting muscle metabolism is also associated with frailty. Frail adults have lower levels of insulin-like growth factor-1 (IGF-1), the signaling target of growth hormone and a key anabolic effector of muscle $(25,33-35)$. Sex hormones are lower in frail adults (i.e., estrogen in women and testosterone in men), as is 25-hydroxyvitamin D (25, 36-40).

\section{Measurement of Frailty}

Frailty is, by definition, a multidimensional syndrome (19). Not surprisingly, numerous instruments have been developed to operationalize its measurement, including clinician assessments, self-reports, physical performance assessments, or combinations of the three. Although numerous, they generally fall into two general models.

The first model considers frailty to be a biological syndrome, identifiable as a distinct phenotype. The Cardiovascular Health Study Index developed by Fried and colleagues (often referred to as the Fried Frailty Phenotype), is the most widely cited example of this model (2). The Fried Frailty Phenotype quantifies deficits in five domains: weakness (measured by hand-grip dynamometry), exhaustion (measured by responses to questions about effort and motivation) (41), shrinking (defined as unintentional weight loss $\geqslant 10$ pounds in the last year), slowness (measured by gait speed over $15 \mathrm{ft}$ ), and low activity (ascertained by estimating kilocalorie expenditure) (42), with frailty being defined as deficits in at least three of these domains. Recent studies suggest that individual frailty domains have varying prognostic utility (43), with gait speed perhaps being the most discriminant predictor of incident disability and survival (44).

The second model, the cumulative deficit approach, defines frailty by enumerating abnormalities, with less attention paid to the specific nature of each problem or its severity. Rockwood and

Figure 1. (Continued). patients who are frail (red line) or not frail (blue line) prior to becoming critically ill. The thickness of the trajectory lines represents the proportion of patients in each trajectory. For a given insult, frail patients are susceptible to becoming critically ill sooner. Patients who are frail prior to critical illness are more likely to die in the hospital and more likely to develop chronic critical illness or severe disability leading to an early death. If they survive their critical illness, they are prone to recover functional status more slowly or develop permanent disability and a shorter lifespan than those who are not frail. 
Table 1. Examples of instruments representative of the phenotype and cumulative deficit models of frailty

\begin{tabular}{|c|c|c|c|c|c|}
\hline Instrument & Reference & $\begin{array}{l}\text { Domains } \\
\text { Assessed }\end{array}$ & $\begin{array}{c}\text { Method of Frailty Domain } \\
\text { Assessment }\end{array}$ & $\begin{array}{l}\text { Populations } \\
\text { Assessed }\end{array}$ & Scoring \\
\hline $\begin{array}{l}\text { Fried Frailty } \\
\text { Phenotype } \\
\text { (FFP) }\end{array}$ & $\begin{array}{l}\text { Fried et al., } \\
2001 \text { (2) }\end{array}$ & $\begin{array}{l}\text { Nutritional status, } \\
\text { physical activity, } \\
\text { mobility, strength, } \\
\text { and energy }\end{array}$ & $\begin{array}{l}\text { Physical tests for slow gait and } \\
\text { low physical activity and } \\
\text { survey-based self-report } \\
\text { assessment of weight loss, } \\
\text { exhaustion, and weakness }\end{array}$ & $\begin{array}{l}\text { Older adults } \\
\text { aged } \geqslant 65 \mathrm{yr}\end{array}$ & $\begin{array}{l}\text { Range: } 0-5 \text {; not frail: } \\
0 \text { frailty factors; prefrail: } \\
\text { 1-2 frailty factors; frail: } \\
\text { ₹3 frailty factors }\end{array}$ \\
\hline $\begin{array}{l}\text { Short Physical } \\
\text { Performance } \\
\text { Battery (SPPB) }\end{array}$ & $\begin{array}{l}\text { Guralnik et al., } \\
1994 \text { (8) }\end{array}$ & $\begin{array}{l}\text { Physical activity, } \\
\text { mobility, strength, } \\
\text { and energy }\end{array}$ & $\begin{array}{l}\text { Battery of physical } \\
\text { performance tests that } \\
\text { include balance (tandem, } \\
\text { semi-tandem, side-by-side), } \\
\text { gait speed (4-m walk), and } \\
\text { strength (sit to stand } 5 \text { times) }\end{array}$ & $\begin{array}{l}\text { Older adults } \\
\quad \text { aged } \geqslant 65 \mathrm{yr}\end{array}$ & $\begin{array}{l}\text { Range: } 0-12 ; \text { not frail: } \\
\geqslant 10 \text { points; prefrail: } \\
8-9 \text { points; frail: } \leqslant 7 \\
\text { points }\end{array}$ \\
\hline $\begin{array}{l}\text { Study of } \\
\text { Osteoporotic } \\
\text { Fractures (SOF) }\end{array}$ & $\begin{array}{l}\text { Kiely et al., } \\
2009 \text { (119) }\end{array}$ & $\begin{array}{l}\text { Nutritional status, } \\
\text { mobility, strength, } \\
\text { and energy }\end{array}$ & $\begin{array}{l}\text { Self-reports of weight loss and } \\
\text { reduced energy level and } \\
\text { performance test of chair } \\
\text { stands to assess weakness }\end{array}$ & $\begin{array}{l}\text { Older adults } \\
\text { aged } \geqslant 70 \mathrm{yr}\end{array}$ & $\begin{array}{l}\text { Range: } 0-3 \text {; not frail: } \\
0 \text { frailty factors; prefrail: } \\
1 \text { frailty factor; frail: } \\
\text { 2-3 frailty factors }\end{array}$ \\
\hline $\begin{array}{l}\text { Frailty Index/ } \\
\text { Accumulation } \\
\text { of Deficits }\end{array}$ & $\begin{array}{l}\text { Rockwood et al., } \\
2006 \text { (120) }\end{array}$ & $\begin{array}{l}\text { Nutritional status, } \\
\text { physical activity, } \\
\text { mobility, strength, } \\
\text { energy, cognition, } \\
\text { mood, and social } \\
\text { relations or social } \\
\text { support }\end{array}$ & $\begin{array}{l}\text { Enumeration of the total } \\
\text { number of health deficits } \\
\text { frequently affecting older } \\
\text { adults out of a potential list of } \\
70-\text { presence or severity of } \\
\text { diseases; deficits in activities } \\
\text { of daily living; clinical and } \\
\text { neurological problems }\end{array}$ & $\begin{array}{l}\text { Older adults } \\
\text { aged } \geqslant 70 \mathrm{yr}\end{array}$ & $\begin{array}{l}\text { Range: } 0-70 ; \text { higher } \\
\text { score indicates } \\
\text { more frail }\end{array}$ \\
\hline $\begin{array}{l}\text { Clinical Frailty } \\
\text { Scale }\end{array}$ & $\begin{array}{l}\text { Rockwood et al., } \\
2005 \text { (10) }\end{array}$ & $\begin{array}{l}\text { Nutritional status, } \\
\text { physical activity, } \\
\text { mobility, strength, } \\
\text { energy, cognition, } \\
\text { mood, and social } \\
\text { relations or social } \\
\text { support }\end{array}$ & $\begin{array}{l}\text { Interview-based assessment } \\
\text { and physician-assigned } \\
\text { score of } 1 \text { (robust health) to } \\
7 \text { (complete functional } \\
\text { dependence on others) }\end{array}$ & $\begin{array}{l}\text { Older adults } \\
\text { aged } \geqslant 65 \mathrm{yr}\end{array}$ & $\begin{array}{l}\text { Range: } 0-7 \text {; not frail: } \\
\text { score of } 1-3 \text {; prefrail: } \\
\text { score of } 4 \text {; frail: score } \\
\text { of } 5-7\end{array}$ \\
\hline
\end{tabular}

colleagues developed the two commonly used cumulative deficit frailty instruments: the Frailty Index and Clinical Frailty scale $(3,10)$. The original Frailty Index includes 70 clinical characteristics and laboratory measures believed to be associated with the development of adverse outcomes. Deficits in these 70 items are counted, and a Frailty Index score is then expressed as a ratio of the deficits present divided by 70 . Because the assessment burden of the Index precludes its routine use in clinical settings, Rockwood and colleagues developed The Clinical Frailty Scale, a seven-point assessment tool wherein a clinician assigns a score on the basis of a patient's physical activity, social connectedness, burden of comorbidities, and cognition.

Although the phenotype and cumulative deficit models are operationally very different, both satisfy validity criteria and predict subsequent poor health outcomes in their target populations. Table 1 outlines some of the more extensively used frailty instruments. Additional instruments are outlined in Table E1 the online supplement.

\section{Frailty in Pulmonary Disease}

The associations between individual pathobiological and clinical constructs underpinning frailty and adverse outcomes in adults with lung disease are well described. For example, patients with COPD exhibit evidence of chronic systemic inflammation and endocrine dysregulation (assessed by biomarkers including IL-6, TNF, C-reactive protein, and IGF-1) compared with those without COPD (45-48). Furthermore, among those with COPD, higher levels of systemic inflammation biomarkers are associated with poorer physical function, exacerbations, and death $(46,49-51)$. Sarcopenia and cachexia are more common in patients with COPD than in matched healthy control subjects and are independently associated with reduced exercise capacity, functional performance, health status, readmission following hospitalization for acute exacerbation, and mortality $(17,46$, 52-54). In addition, adults with COPD exhibit skeletal muscle dysfunction at the biochemical, cellular, and structural levels $(13,55-57)$.

Although most information is derived from those with COPD, a U.S. national registry study showed that lower 6-minutewalk distance is associated with mortality in adults with interstitial lung disease awaiting lung transplantation (58). In addition, lower preoperative 6-minute-walk distance and serum albumin (potentially reflecting malnutrition) is associated with mortality after lung transplantation across disease types $(59,60)$.

\section{Identifying and Measuring Frailty in Patients with Lung Disease}

Studies of frailty in adults with lung disease using validated instruments, however, are few and have focused on COPD or mixed populations of lung disease. Mittal and colleagues studied 120 patients with COPD, asthma, pulmonary fibrosis, or pulmonary arterial hypertension (61). The cohort was $18 \%$ frail (Fried Frailty Phenotype $\geqslant 3$ ), $64 \%$ prefrail (Fried Frailty Phenotype $=2$ ), and $18 \%$ not frail (Fried Frailty Phenotype $<2$ ). The prevalence of frailty 
across lung disease types was not reported. Frail patients reported more frequent hospitalizations and falls than others. Frailty appeared to be associated with greater likelihood of hospitalizations: $76 \%$ of frail subjects, $60 \%$ of prefrail subjects, and $32 \%$ of not-frail subjects reported being hospitalized one or more times in the preceding year. A similar pattern was observed for falls. Notably, the authors defined "not frail" as meeting fewer than two criteria, whereas the more commonly accepted threshold defines "not frail" as meeting no frailty features. It is possible that the observed trends toward more hospitalizations and falls would have been greater if more commonly accepted thresholds had been used.

Lahousse and colleagues evaluated 2,146 community-dwelling older adults who completed Fried frailty assessments and spirometry (62). Of this group, 402 (19\%) were diagnosed with COPD. Those with COPD were more likely to be frail than those without ( 10.2 vs. $3.4 \%$; $P<0.001)$, and the severity of COPD appeared to be independently associated with being frail. After multivariable adjustment, compared with those without COPD, those with COPD without frequent exacerbations had 2.5-fold higher odds of being frail, and those with COPD and frequent exacerbations had 4.5-fold higher odds of being frail. Although the risk of death was similar in nonfrail patients with and without COPD, frail patients with COPD had a nearly threefold higher mortality rate than either of these two groups. Notably, frailty was a stronger predictor of mortality than was $\mathrm{FEV}_{1} \%$ predicted or comorbidities.

\section{Implications of Frailty in Patients with Chronic Lung Disease}

In a study of 3,578 participants in the Cardiovascular Health Study, Vaz Fragoso and colleagues evaluated the relationship between a modified version of Fried's frailty instrument and respiratory impairments defined as either airflow limitation or restriction by spirometry (63). Participants completed a battery of assessments at baseline and at 4 years and had up to 12 years of vital status follow up. Prefrail and frail patients had $42 \%$ higher odds of developing respiratory impairments at follow up than those who were nonfrail, adjusting for relevant covariates.

Conversely, after adjusting for the same factors, those with respiratory impairments at baseline had 58\% higher odds of developing prefrailty or frailty at follow up than those without impairments. The impact of baseline respiratory impairments and frailty status on mortality appeared to be synergistic. Compared with nonfrail subjects with normal respiratory function, frail subjects with respiratory impairments had a nearly fourfold higher risk of death. This risk was at least twofold higher than that of nonfrail subjects with respiratory impairments or frail subjects without respiratory impairments.

Galizia and colleagues evaluated the impact of frailty on mortality in older adults with and without COPD (64). Subjects completed baseline assessments used to calculate the Frailty Staging System, a multidimensional count of deficits. Frailty was defined as mild, moderate, or severe. In those with COPD, 12-year mortality was $42 \%$ in nonfrail subjects, $53 \%$ in subjects with mild frailty, and $97 \%$ in subjects with severe frailty (test of trend $P<0.001$ ). Each one-deficit increase in Frailty Staging System was associated with an $80 \%$ increased risk of death after covariate adjustment.

In a multicenter prospective cohort study, we evaluated the validity of the Fried Frailty Phenotype and Short Physical Performance Battery frailty measures in 395 candidates for lung transplantation with a mix of lung diseases (65). Among the cohort, 28\% were frail by Fried Frailty Phenotype and $10 \%$ by the Short Physical Performance Battery. Frailty prevalence was similar across disease types. By either measure, worsening frailty scores were independently associated with increased disability. Furthermore, worsening frailty scores were independently associated with an increased rate of death or being removed from the wait-list because of clinical deterioration.

After covariate adjustment, each SD worsening in the Short Physical Performance Battery was associated with a threefold higher risk of death or delisting, and each SD worsening in the Fried Frailty Phenotype score was associated with a roughly $40 \%$ increased risk of death or delisting. Frail transplant candidates had protein biomarker evidence of systemic inflammation (higher levels of IL-6 and TNF-receptor 1), cachexia (lower levels of leptin), and aging (lower levels of IGF-1). The study is focusing now on whether preoperative frailty is associated with posttransplant complications, disability, and death.

In summary, frailty is independently associated with lower exercise capacity, disability, falls, hospitalizations, and mortality in adults with lung disease. Furthermore, the impact of lung disease and frailty on respiratory function and mortality appears to be synergistic, suggesting a more complicated relationship than simply one of comorbid conditions. These observations, particularly in patients with COPD, suggest that the mechanisms driving frailty outlined in Figure 2 (e.g., inflammation, endocrine dysfunction, muscle wasting) may also drive the progression of chronic lung disease and vice versa.

\section{Frailty in Critical Illness}

Older adults (aged $\geqslant 65$ years) comprise about half of all intensive care admissions in high-income countries, receive more intensive treatments than in the past, and are more likely to survive critical illness than ever before $(66,67)$. Recognizing a need to identify those most suitable for palliative, rehabilitative, and therapeutic interventions $(68,69)$, investigators have begun examining frailty in older critically ill patients and survivors of critical illness.

\section{Frailty on Admission to an Intensive Care Unit}

In the largest study of frailty in critical illness to date, investigators measured the Clinical Frailty Score (10) at intensive care unit (ICU) admission in 421 adults aged 50 years or older across six hospitals. Defining frailty as a Clinical Frailty Score greater than $4,33 \%$ were frail on ICU admission. Independent of age, sex, critical illness severity, and comorbidities, frail adults were twice as likely to die in the hospital (32 vs. 16\%; adjusted odds ratio, 1.81; $95 \%$ confidence interval [CI], 1.09-3.01) and were twice as likely to die within 1 year (48 vs. $25 \%$; adjusted hazard ratio, 1.82; $95 \%$ CI, 1.28-2.60). Frail adults were also more likely to be functionally dependent at hospital discharge and have lower healthrelated quality of life in the subsequent year $(70,71)$.

A multicenter prospective cohort study of 196 intensive care patients aged 65 years or older found similar independent associations between prehospitalization 
frailty measured by Clinical Frailty Score and in-hospital and 6-month mortality (12). Investigators also measured prehospitalization frailty by the Fried Frailty Phenotype, although measurements of grip strength and walk speed were replaced with self- or proxy reports of mobility before critical illness that made the assessment possible in the ICU environment but may have compromised its construct validity. The modified frailty phenotype was independently associated with ICU, but not longer-term, mortality.

\section{Frailty in Survivors of Critical Illnesses}

The frailty deficits of undernutrition, weight loss, muscle wasting, and weakness that typically take years to develop in outpatient geriatric populations can develop or worsen rapidly in the critically ill, regardless of the specific critical illness diagnosis $(68,72)$. Therefore, measuring the Fried Frailty Phenotype domains in the heterogeneous population of survivors of critical illness may help posthospitalization outcome prognostication as well as identify potential deficits as therapeutic targets for intervention.

To date, one pilot study has demonstrated the feasibility of measuring Fried's frailty components in older medical survivors of critical illness after they were moved to the general ward. Once out of the ICU, they were usually able to answer questions and participate in dynamic assessments (73). Investigators modified certain Fried Frailty Phenotype domains to address measurement challenges in an ICU population: (1) those unable to walk were considered slow, (2) physical activity was based on leisure activities performed in the month before hospitalization, (3) feelings of exhaustion were assessed during the week before anticipated hospital discharge, and (4) next of kin answered questions if the subject was too debilitated to answer or could not remember. Using Fried's established cutoffs for each component and defining frailty as three or more deficits, $81 \%$ of older survivors of critical illness were frail. In unadjusted analyses, each 1-point increase in Fried frailty score was associated with a threefold increase in 6-month mortality (relative risk, 3.0; 95\% CI, 1.4-6.3), and those with a score of 5 had an 83\% 6-month mortality. A larger study to assess the independent association between post-ICU frailty and outcomes is ongoing.
These studies inform debates regarding the value of intensive care for older adults $(67,74,75)$. Collectively, they suggest that older adults without frailty prior to critical illness may benefit most from intensive care, whereas those who are frail prior to critical illness are more likely to die in the hospital or are more likely to develop chronic critical illness or severe disability leading to early death (Figure 1B). These studies also highlight advantages and disadvantages with the cumulative deficit and phenotype approaches to frailty assessment. Cumulative deficit models may be most useful when frailty status needs to be known at ICU admission to screen patients into prospective cohort studies or trials or for retrospective studies that involve medical record review.

Alternatively, phenotype models may be more useful for mechanistic studies that seek to understand the pathobiology of frailty in critical illness or as an outcome measure of response to interventions.

\section{Biological Correlates of Frailty in Critically III Adults}

In addition to clinical frailty assessments, investigators have examined biological components of frailty in critically ill adults, with a focus on muscle wasting and sarcopenia.

In a cohort of medical and surgical critically ill adults requiring mechanical ventilation, muscle wasting occurred rapidly during the first week of critical illness (76). Wasting was evidenced by a reduction in rectus femoris cross-sectional area measured by ultrasonography and decreased muscle protein synthesis and increased muscle protein breakdown measured by muscle biopsy. Low skeletal muscle mass, estimated by the crosssectional area of muscle on abdominal CT scan, a previously validated measure of sarcopenia in older adults (77), is independently associated with in-hospital mortality in older trauma ICU patients and adults receiving mechanical ventilation $(78$, 79). These findings are consistent with prior studies in community-dwelling older adults showing low muscle mass increases the risk for subsequent disability and mortality (80-82).

Although a mild proinflammatory state (e.g., elevated TNF- $\alpha$, IL-6) and decreased levels of anabolic hormones (e.g., IGF-1, dehydroepiandrosterone, testosterone) are associated with frailty in community- dwelling older adults $(23,35,83,84)$, these associations have not been evaluated in the critically ill or survivors of critical illness. However, two studies suggest that these associations may hold true in these populations as well. First, a study of older survivors of community-acquired pneumonia ( $14 \%$ of whom received ICU care) found that those with elevated levels of IL- 6 and IL-10 within 48 hours prior to discharge had an increased risk of death over 1 year, independent of their severity of illness, age, and comorbidities (85). Second, a study that measured several hormones in critically ill subjects on the first day they regained consciousness following at least 7 days of mechanical ventilation showed that lower levels of IGF-1 and dehydroepiandrosterone were associated with in-hospital mortality (86).

\section{Moving Forward}

\section{Refining Frailty Measurement in Pulmonary and Critical Care Medicine}

It is likely that refinements to existing instruments may be needed for frailty assessment in lung disease and critical illness. Although existing instruments conceptually have face validity and the instruments described above have reasonable construct and predictive validity in lung disease and critical illness, none were developed specifically for these populations $(2,10)$. Some of the constructs, such as low activity or exhaustion in the Fried Frailty Phenotype, for example, may be confounded by lung disease or critical illness resulting in an overestimation of frailty. Furthermore, some single frailty constructs may explain the majority of the observed association between frailty and poor outcomes.

For example, slow gait speed is strongly associated with frailty and is also a powerful individual predictor of poor outcomes, including mortality-so much so that gait speed has been referred to as the "sixth vital sign" $(43,44,87)$. Future work should focus on refining the operational measure of frailty in lung disease and critical illness through careful consideration of the measures used to assess theoretical constructs and validating the discriminant function and calibration of the overall instrument. Adding imaging or biomarker assessments may improve the instrument risk prediction. 
Measurement of frailty in adults with lung disease has the potential to meaningfully affect clinical care. Frailty assessment may improve prognostication and explain functional limitations and disability that appear to be out of proportion to pulmonary impairment. Recent studies have shown that preoperative frailty and sarcopenia are associated with postoperative complications and mortality after major surgery (88-92). Measuring frailty in adults with lung disease preparing to undergo surgery-a group already at heightened risk for complications-could further improve risk stratification. Also, in lung transplantation, frailty assessment holds promise. Indeed, if frailty is associated with poor outcomes after transplant, preoperative assessment may identify patients unlikely to benefit from the intervention. If it is not, frail patients should be prioritized for organ allocation (93).

In those who are critically ill or have survived critical illness, frailty clearly identifies patients at greater risk for shortand longer-term dependency and mortality. Frailty assessment may therefore inform shared decision making about goals of care, particularly for older adults in the ICU (72). Second, assessing frailty before and immediately after critical illness may improve risk stratification and identify subgroups who may be most suitable for post-ICU palliative, rehabilitative, or therapeutic interventions. Indeed, better identification of survivors of critical illness at risk for persistent disability is needed in light of fact that three recent trials of post-ICU rehabilitation failed to detect a benefit, perhaps in part because too many survivors of critical illness, especially the young, recovered function with usual care, potentially diluting the treatment effect of rehabilitation (94-97).

\section{Frailty as a Therapeutic Target in Pulmonary Disease and Critical Illness}

Recent work in older populations shows that frailty may be reversible through targeted exercise and nutrition interventions (11, 98, 99). That muscle wasting, weakness, and malnutrition (hallmarks of frailty) are common in those with lung disease and should be responsive to physical exercise training and nutrition optimization underscores the importance of rehabilitation. Treating these frailty constructs may partially explain why pulmonary rehabilitation improves exercise capacity, disability, healthrelated quality of life, and, in COPD, reduces hospitalizations and mortality $(100,101)$.

Furthermore, if frailty is associated with postoperative complications in patients with lung disease, interventions aimed at reversing frailty could allow patients to undergo elective surgery in an optimized physical and nutritional state

(i.e., "pre-habilitation"), potentially reducing postoperative complications, disability, and mortality (102). For lung transplant candidates, such interventions might reduce wait-list delisting or death as well as complications after transplant surgery. Notably, it is not clear whether the pathobiology causing frailty is universal across diverse lung diseases with heterogeneous pathophysiology or whether it differs by groups such as disease category underlying mechanisms (e.g., hyperinflammatory vs. sarcopenic or malnourished). Clarifying these questions could identify subgroups at differential risk for poor outcomes and inform tailoring of interventions.

In the ICU, our current evidence base suggests that we should first and foremost prevent frailty through minimizing sedation and through early mobilization, which have been shown to reduce ICU delirium as well as disability at hospital discharge (103). Further development and testing of novel rehabilitative therapies for critically ill patients and survivors of critical illness who are too weak to sit or walk is urgently needed (e.g., bedside cycle ergometry [104], neuromuscular electrical stimulation $[105,106])$. Recent mechanistic research has begun to elucidate the molecular mechanisms of skeletal muscle dysfunction and wasting in aging and critical illness $(76,107,108)$, which, in turn, has identified novel pharmaceutical targets to prevent muscle wasting and improve recovery of muscle function (e.g., ubiquitin proteasome system mediators [109], myostatin agonists [110]).

Prior efforts to treat the frailty deficits of undernutrition and endocrine dysfunction during critical illness underscores that caution must be exercised in differentiating between adaptive and maladaptive deficits. Trials to treat undernutrition during critical illness with supplemental nutrition have been ineffective and might have actually potentiated muscle atrophy and weakness (15, 76, 111-114), and a trial of growth hormone replacement in acutely critically ill medical and surgical patients doubled the risk of in-hospital death (115). In light of these studies, there is developing interest in targeting nutritional supplementation and hormone replacement therapies after ICU discharge to reverse weight loss and exhaustion in survivors of critical illness $(116,117)$.

\section{Summary}

Originally a geriatric construct, frailty is a generalized vulnerability to stressors resulting from an accumulation of physiologic deficits across multiple interrelated systems. Frailty is relatively common in subjects with lung disease and critical illness and is independently associated with poor functional status, exacerbations of lung disease, disability, poor health-related quality of life, and mortality. Assessing frailty may help clinicians identify patients at heightened risk for poor outcomes and those who may respond to targeted interventions. Multipronged efforts are needed aimed at refining clinical frailty assessments, understanding the mechanisms, and developing interventions targeting frailty in lung disease and critical illness that aim to preserve functional independence, reduce disability, and improve survival.

Author disclosures are available with the text of this article at www. atsjournals.org.

\section{References}

1 Cowdry EV. Problems of ageing: biological and medical aspects, 2nd ed. Baltimore: Williams and Wilkins; 1942.

2 Fried LP, Tangen CM, Walston J, Newman AB, Hirsch C, Gottdiener J, Seeman T, Tracy R, Kop WJ, Burke G, et al.; Cardiovascular Health
Study Collaborative Research Group. Frailty in older adults: evidence for a phenotype. J Gerontol A Biol Sci Med Sci 2001;56: M146-M156.

3 Mitnitski AB, Mogilner AJ, Rockwood K. Accumulation of deficits as a proxy measure of aging. ScientificWorldJournal 2001;1: 323-336. 
4 Lin CC, Li Cl, Chang CK, Liu CS, Lin CH, Meng NH, Lee YD, Chen FN, $\mathrm{Li}$ TC. Reduced health-related quality of life in elders with frailty: a cross-sectional study of community-dwelling elders in Taiwan. Plos One 2011;6:e21841.

5 Masel MC, Ostir GV, Ottenbacher KJ. Frailty, mortality, and healthrelated quality of life in older Mexican Americans. J Am Geriatr Soc 2010;58:2149-2153.

6 Saum KU, Dieffenbach AK, Müller H, Holleczek B, Hauer K, Brenner H. Frailty prevalence and 10-year survival in community-dwelling older adults: results from the ESTHER cohort study. Eur J Epidemiol 2014;29:171-179.

7 Shamliyan T, Talley KM, Ramakrishnan R, Kane RL. Association of frailty with survival: a systematic literature review. Ageing Res Rev 2013;12:719-736.

8 Guralnik JM, Simonsick EM, Ferrucci L, Glynn RJ, Berkman LF, Blazer DG, Scherr PA, Wallace RB. A short physical performance battery assessing lower extremity function: association with self-reported disability and prediction of mortality and nursing home admission. J Gerontol 1994;49:M85-M94.

9 Guralnik JM, Ferrucci L, Simonsick EM, Salive ME, Wallace RB. Lower-extremity function in persons over the age of 70 years as a predictor of subsequent disability. N Engl J Med 1995;332: 556-561.

10 Rockwood K, Song X, MacKnight C, Bergman H, Hogan DB, McDowell I, Mitnitski A. A global clinical measure of fitness and frailty in elderly people. CMAJ 2005;173:489-495.

11 Latham NK, Harris BA, Bean JF, Heeren T, Goodyear C, Zawacki S, Heislein DM, Mustafa J, Pardasaney P, Giorgetti M, et al. Effect of a home-based exercise program on functional recovery following rehabilitation after hip fracture: a randomized clinical trial. JAMA 2014;311:700-708.

12 Le Maguet $\mathrm{P}$, Roquilly A, Lasocki S, Asehnoune K, Carise E, Saint Martin M, Mimoz O, Le Gac G, Somme D, Cattenoz C, et al. Prevalence and impact of frailty on mortality in elderly ICU patients: a prospective, multicenter, observational study. Intensive Care Med 2014;40:674-682.

13 Mathur S, Brooks D, Carvalho CR. Structural alterations of skeletal muscle in COPD. Front Physiol 2014;5:104.

14 Morley JE, Vellas B, van Kan GA, Anker SD, Bauer JM, Bernabei R, Cesari M, Chumlea WC, Doehner W, Evans J, et al. Frailty consensus: a call to action. J Am Med Dir Assoc 2013;14:392-397.

15 Needham DM, Dinglas VD, Morris PE, Jackson JC, Hough CL, Mendez-Tellez PA, Wozniak AW, Colantuoni E, Ely EW, Rice TW, et al.; NIH NHLBI ARDS Network. Physical and cognitive performance of patients with acute lung injury 1 year after initial trophic versus full enteral feeding. EDEN trial follow-up. Am J Respir Crit Care Med 2013;188:567-576.

16 Newman AB, Gottdiener JS, Mcburnie MA, Hirsch CH, Kop WJ, Tracy R, Walston JD, Fried LP; Cardiovascular Health Study Research Group. Associations of subclinical cardiovascular disease with frailty. J Gerontol A Biol Sci Med Sci 2001;56:M158-M166.

17 Sergi G, Coin A, Marin S, Vianello A, Manzan A, Peruzza S, Inelmen EM, Busetto L, Mulone S, Enzi G. Body composition and resting energy expenditure in elderly male patients with chronic obstructive pulmonary disease. Respir Med 2006;100:1918-1924.

18 López-Otín C, Blasco MA, Partridge L, Serrano M, Kroemer G. The hallmarks of aging. Cell 2013;153:1194-1217.

19 Walston J, Hadley EC, Ferrucci L, Guralnik JM, Newman AB, Studenski SA, Ershler WB, Harris T, Fried LP. Research agenda for frailty in older adults: toward a better understanding of physiology and etiology: summary from the American Geriatrics Society/ National Institute on Aging Research Conference on Frailty in Older Adults. J Am Geriatr Soc 2006;54:991-1001.

20 Chen X, Mao G, Leng SX. Frailty syndrome: an overview. Clin Interv Aging 2014;9:433-441.

21 Leng S, Chaves P, Koenig K, Walston J. Serum interleukin-6 and hemoglobin as physiological correlates in the geriatric syndrome of frailty: a pilot study. J Am Geriatr Soc 2002;50:1268-1271.

22 Hubbard RE, O'Mahony MS, Calver BL, Woodhouse KW. Nutrition, inflammation, and leptin levels in aging and frailty. J Am Geriatr Soc 2008;56:279-284.
23 Hubbard RE, O'Mahony MS, Savva GM, Calver BL, Woodhouse KW. Inflammation and frailty measures in older people. $J$ Cell Mol Med 2009;13:3103-3109.

24 Cesari M, Penninx BW, Pahor M, Lauretani F, Corsi AM, Rhys Williams G, Guralnik JM, Ferrucci L. Inflammatory markers and physical performance in older persons: the InCHIANTI study. J Gerontol A Biol Sci Med Sci 2004;59:242-248.

25 Puts MT, Visser M, Twisk JW, Deeg DJ, Lips P. Endocrine and inflammatory markers as predictors of frailty. Clin Endocrinol (Oxf) 2005;63:403-411.

26 Walston J, McBurnie MA, Newman A, Tracy RP, Kop WJ, Hirsch CH Gottdiener J, Fried LP; Cardiovascular Health Study. Frailty and activation of the inflammation and coagulation systems with and without clinical comorbidities: results from the Cardiovascular Health Study. Arch Intern Med 2002;162:2333-2341.

27 Barzilay JI, Blaum C, Moore T, Xue QL, Hirsch CH, Walston JD, Fried LP. Insulin resistance and inflammation as precursors of frailty: the Cardiovascular Health Study. Arch Intern Med 2007; 167:635-641.

28 Cesari M, Landi F, Vellas B, Bernabei R, Marzetti E. Sarcopenia and physical frailty: two sides of the same coin. Front Aging Neurosci 2014;6:192.

29 Studenski SA, Peters KW, Alley DE, Cawthon PM, McLean RR, Harris TB, Ferrucci L, Guralnik JM, Fragala MS, Kenny AM, et al. The FNIH sarcopenia project: rationale, study description, conference recommendations, and final estimates. J Gerontol A Biol Sci Med Sci 2014;69:547-558

30 Morley JE. Sarcopenia in the elderly. Fam Pract 2012;29:i44-i48.

31 Haddad F, Zaldivar F, Cooper DM, Adams GR. IL-6-induced skeletal muscle atrophy. J Appl Physiol (1985) 2005;98:911-917.

32 Llovera M, López-Soriano FJ, Argilés JM. Effects of tumor necrosis factor-alpha on muscle-protein turnover in female Wistar rats. $J$ Natl Cancer Inst 1993;85:1334-1339.

33 Leng SX, Hung W, Cappola AR, Yu Q, Xue QL, Fried LP. White blood cell counts, insulin-like growth factor-1 levels, and frailty in community-dwelling older women. J Gerontol A Biol Sci Med Sci 2009;64:499-502.

34 Cappola AR, Xue QL, Ferrucci L, Guralnik JM, Volpato S, Fried LP. Insulin-like growth factor I and interleukin-6 contribute synergistically to disability and mortality in older women. $J$ Clin Endocrinol Metab 2003;88:2019-2025.

35 Leng SX, Cappola AR, Andersen RE, Blackman MR, Koenig K, Blair $M$, Walston JD. Serum levels of insulin-like growth factor-I (IGF-I) and dehydroepiandrosterone sulfate (DHEA-S), and their relationships with serum interleukin-6, in the geriatric syndrome of frailty. Aging Clin Exp Res 2004;16:153-157.

36 Cawthon PM, Ensrud KE, Laughlin GA, Cauley JA, Dam TT, BarrettConnor E, Fink HA, Hoffman AR, Lau E, Lane NE, et al.; Osteoporotic Fractures in Men (MrOS) Research Group. Sex hormones and frailty in older men: the osteoporotic fractures in men (MrOS) study. J Clin Endocrinol Metab 2009;94:3806-3815.

37 Joseph C, Kenny AM, Taxel P, Lorenzo JA, Duque G, Kuchel GA Role of endocrine-immune dysregulation in osteoporosis, sarcopenia, frailty and fracture risk. Mol Aspects Med 2005;26: 181-201.

38 Tiidus PM, Lowe DA, Brown M. Estrogen replacement and skeletal muscle: mechanisms and population health. J Appl Physiol (1985) 2013;115:569-578.

39 Travison TG, Nguyen AH, Naganathan V, Stanaway FF, Blyth FM, Cumming RG, Le Couteur DG, Sambrook PN, Handelsman DJ. Changes in reproductive hormone concentrations predict the prevalence and progression of the frailty syndrome in older men: the concord health and ageing in men project. J Clin Endocrinol Metab 2011;96:2464-2474.

40 Shardell M, Hicks GE, Miller RR, Kritchevsky S, Andersen D, Bandinelli $S$, Cherubini A, Ferrucci L. Association of low vitamin $D$ levels with the frailty syndrome in men and women. $J$ Gerontol A Biol Sci Med Sci 2009;64:69-75.

41 Radloff LS. The CES-D scale: a self-report depression scale for research in the general population. Appl Psychol Meas 1977;1: 385-401. 
42 Taylor HL, Jacobs DR Jr, Schucker B, Knudsen J, Leon AS, Debacker G. A questionnaire for the assessment of leisure time physical activities. J Chronic Dis 1978;31:741-755.

43 Rothman MD, Leo-Summers L, Gill TM. Prognostic significance of potential frailty criteria. J Am Geriatr Soc 2008;56:2211-2216.

44 Studenski S, Perera S, Patel K, Rosano C, Faulkner K, Inzitari M, Brach J, Chandler J, Cawthon P, Connor EB, et al. Gait speed and survival in older adults. JAMA 2011;305:50-58.

45 Breyer MK, Rutten EP, Locantore NW, Watkins ML, Miller BE, Wouters EF; ECLIPSE Investigators (Evaluation of COPD Longitudinally to Identify Predictive Surrogate Endpoints). Dysregulated adipokine metabolism in chronic obstructive pulmonary disease. Eur J Clin Invest 2012;42:983-991.

46 Schols AM, Buurman WA, Staal van den Brekel AJ, Dentener MA, Wouters EF. Evidence for a relation between metabolic derangements and increased levels of inflammatory mediators in a subgroup of patients with chronic obstructive pulmonary disease. Thorax 1996;51:819-824.

47 Gan WQ, Man SF, Senthilselvan A, Sin DD. Association between chronic obstructive pulmonary disease and systemic inflammation: a systematic review and a meta-analysis. Thorax 2004;59:574-580.

48 Laghi F, Adiguzel N, Tobin MJ. Endocrinological derangements in COPD. Eur Respir J 2009;34:975-996.

49 Agustí A, Edwards LD, Rennard SI, MacNee W, Tal-Singer R, Miller BE, Vestbo J, Lomas DA, Calverley PM, Wouters E, et al.; Evaluation of COPD Longitudinally to Identify Predictive Surrogate Endpoints (ECLIPSE) Investigators. Persistent systemic inflammation is associated with poor clinical outcomes in COPD: a novel phenotype. Plos One 2012;7:e37483.

50 Karadag F, Karul AB, Cildag O, Yilmaz M, Ozcan H. Biomarkers of systemic inflammation in stable and exacerbation phases of COPD. Lung 2008;186:403-409.

51 Thomsen M, Ingebrigtsen TS, Marott JL, Dahl M, Lange P, Vestbo J, Nordestgaard BG. Inflammatory biomarkers and exacerbations in chronic obstructive pulmonary disease. JAMA 2013;309: 2353-2361.

52 Schols AM, Broekhuizen R, Weling-Scheepers CA, Wouters EF. Body composition and mortality in chronic obstructive pulmonary disease. Am J Clin Nutr 2005;82:53-59.

53 Jones SE, Maddocks M, Kon SS, Canavan JL, Nolan CM, Clark AL, Polkey MI, Man WD. Sarcopenia in COPD: prevalence, clinical correlates and response to pulmonary rehabilitation. Thorax 2015; 70:213-218.

54 Greening NJ, Harvey-Dunstan TC, Chaplin EJ, Vincent EE, Morgan MD, Singh SJ, Steiner MC. Bedside assessment of quadriceps muscle by ultrasound after admission for acute exacerbations of chronic respiratory disease. Am J Respir Crit Care Med 2015;192: 810-816.

55 Gifford JR, Trinity JD, Layec G, Garten RS, Park SY, Rossman MJ, Larsen S, Dela F, Richardson RS. Quadriceps exercise intolerance in patients with chronic obstructive pulmonary disease: the potential role of altered skeletal muscle mitochondrial respiration. J Appl Physiol (1985) 2015;119:882-888.

56 Ionescu AA, Chatham K, Davies CA, Nixon LS, Enright S, Shale DJ. Inspiratory muscle function and body composition in cystic fibrosis. Am J Respir Crit Care Med 1998;158:1271-1276.

57 Maltais F, Decramer M, Casaburi R, Barreiro E, Burelle Y, Debigaré R, Dekhuijzen PN, Franssen F, Gayan-Ramirez G, Gea J, et al.; ATS/ERS Ad Hoc Committee on Limb Muscle Dysfunction in COPD. An official American Thoracic Society/European Respiratory Society statement: update on limb muscle dysfunction in chronic obstructive pulmonary disease. Am J Respir Crit Care Med 2014; 189:e15-e62.

58 Lederer DJ, Arcasoy SM, Wilt JS, D'Ovidio F, Sonett JR, Kawut SM. Six-minute-walk distance predicts waiting list survival in idiopathic pulmonary fibrosis. Am J Respir Crit Care Med 2006;174:659-664.

59 Baldwin MR, Arcasoy SM, Shah A, Schulze PC, Sze J, Sonett JR, Lederer DJ. Hypoalbuminemia and early mortality after lung transplantation: a cohort study. Am J Transplant 2012;12: 1256-1267.
60 Castleberry AW, Englum BR, Snyder LD, Worni M, Osho AA, Gulack BC, Palmer SM, Davis RD, Hartwig MG. The utility of preoperative six-minute-walk distance in lung transplantation. Am J Respir Crit Care Med 2015;192:843-852.

61 Mittal N, Raj R, Islam EA, Nugent K. The frequency of frailty in ambulatory patients with chronic lung diseases. J Prim Care Community Health 2016;7:10-15.

62 Lahousse L, Ziere G, Verlinden VJ, Zillikens MC, Uitterlinden AG, Rivadeneira F, Tiemeier H, Joos GF, Hofman A, Ikram MA, et al. Risk of frailty in elderly with COPD: a population-based study. J Gerontol A Biol Sci Med Sci 2016;71:689-695.

63 Vaz Fragoso CA, Enright PL, McAvay G, Van Ness PH, Gill TM. Frailty and respiratory impairment in older persons. Am J Med 2012;125: 79-86.

64 Galizia G, Cacciatore F, Testa G, Della-Morte D, Mazzella F, Langellotto A, Raucci C, Gargiulo G, Ferrara N, Rengo F, et al. Role of clinical frailty on long-term mortality of elderly subjects with and without chronic obstructive pulmonary disease. Aging Clin Exp Res 2011;23:118-125.

65 Singer JP, Diamond JM, Gries CJ, McDonnough J, Blanc PD, Shah R, Dean MY, Hersh B, Wolters PJ, Tokman S, et al. Frailty phenotypies, disability, and outcomes in adult candidates for lung transplantation. Am J Respir Crit Care Med 2015;192:1325-1334.

66 Angus DC, Shorr AF, White A, Dremsizov TT, Schmitz RJ, Kelley MA; Committee on Manpower for Pulmonary and Critical Care Societies (COMPACCS). Critical care delivery in the United States: distribution of services and compliance with Leapfrog recommendations. Crit Care Med 2006;34:1016-1024.

67 Lerolle N, Trinquart L, Bornstain C, Tadié JM, Imbert A, Diehl JL, Fagon JY, Guérot E. Increased intensity of treatment and decreased mortality in elderly patients in an intensive care unit over a decade. Crit Care Med 2010;38:59-64.

68 McDermid RC, Stelfox HT, Bagshaw SM. Frailty in the critically ill: a novel concept. Crit Care 2011;15:301.

69 Baldwin MR. Measuring and predicting long-term outcomes in older survivors of critical illness. Minerva Anestesiol 2015;81:650-661.

70 Bagshaw SM, Stelfox HT, McDermid RC, Rolfson DB, Tsuyuki RT, Baig N, Artiuch B, Ibrahim Q, Stollery DE, Rokosh E, et al. Association between frailty and short- and long-term outcomes among critically ill patients: a multicentre prospective cohort study. CMAJ 2014;186:E95-E102.

71 Bagshaw SM, Stelfox HT, Johnson JA, McDermid RC, Rolfson DB, Tsuyuki RT, Ibrahim Q, Majumdar SR. Long-term association between frailty and health-related quality of life among survivors of critical illness: a prospective multicenter cohort study. Crit Care Med 2015;43:973-982.

72 Bagshaw SM, McDermid RC. The role of frailty in outcomes from critical illness. Curr Opin Crit Care 2013;19:496-503.

73 Baldwin MR, Reid MC, Westlake AA, Rowe JW, Granieri EC, Wunsch H, Dam TT, Rabinowitz D, Goldstein NE, Maurer MS, et al. The feasibility of measuring frailty to predict disability and mortality in older medical intensive care unit survivors. J Crit Care 2014;29:401-408.

74 McDermid RC, Bagshaw SM. Octogenarians in the ICU: are you ever too old? Crit Care 2011;15:125.

75 Roch A, Wiramus S, Pauly V, Forel JM, Guervilly C, Gainnier M, Papazian L. Long-term outcome in medical patients aged 80 or over following admission to an intensive care unit. Crit Care 2011; 15:R36.

76 Puthucheary ZA, Rawal J, McPhail M, Connolly B, Ratnayake G, Chan P, Hopkinson NS, Phadke R, Dew T, Sidhu PS, et al. Acute skeletal muscle wasting in critical illness. JAMA 2013;310:1591-1600.

77 Shen W, Punyanitya M, Wang Z, Gallagher D, St-Onge MP, Albu J, Heymsfield SB, Heshka S. Total body skeletal muscle and adipose tissue volumes: estimation from a single abdominal cross-sectional image. J Appl Physiol (1985) 2004;97:2333-2338.

78 Moisey LL, Mourtzakis M, Cotton BA, Premji T, Heyland DK, Wade CE, Bulger E, Kozar RA; Nutrition and Rehabilitation Investigators Consortium (NUTRIC). Skeletal muscle predicts ventilator-free days, ICU-free days, and mortality in elderly ICU patients. Crit Care 2013;17:R206. 
79 Weijs PJ, Looijaard WG, Dekker IM, Stapel SN, Girbes AR, Oudemans-van Straaten HM, Beishuizen A. Low skeletal muscle area is a risk factor for mortality in mechanically ventilated critically ill patients. Crit Care 2014;18:R12.

80 Bianchi L, Ferrucci L, Cherubini A, Maggio M, Bandinelli S, Savino E, Brombo G, Zuliani G, Guralnik JM, Landi F, et al. The predictive value of the EWGSOP definition of sarcopenia: results from the InCHIANTI study. J Gerontol A Biol Sci Med Sci 2016;71:259-264.

81 Dufour AB, Hannan MT, Murabito JM, Kiel DP, McLean RR. Sarcopenia definitions considering body size and fat mass are associated with mobility limitations: the Framingham Study. J Gerontol A Biol Sci Med Sci 2013;68:168-174.

82 McLean RR, Shardell MD, Alley DE, Cawthon PM, Fragala MS, Harris TB, Kenny AM, Peters KW, Ferrucci L, Guralnik JM, et al. Criteria for clinically relevant weakness and low lean mass and their longitudinal association with incident mobility impairment and mortality: the foundation for the National Institutes of Health (FNIH) sarcopenia project. J Gerontol A Biol Sci Med Sci 2014; 69:576-583.

83 Bandeen-Roche K, Walston JD, Huang Y, Semba RD, Ferrucci L. Measuring systemic inflammatory regulation in older adults: evidence and utility. Rejuvenation Res 2009;12:403-410.

84 Cappola AR, Xue QL, Fried LP. Multiple hormonal deficiencies in anabolic hormones are found in frail older women: the Women's Health and Aging studies. J Gerontol A Biol Sci Med Sci 2009;64: 243-248.

85 Yende S, D'Angelo G, Kellum JA, Weissfeld L, Fine J, Welch RD, Kong L, Carter M, Angus DC; GenIMS Investigators. Inflammatory markers at hospital discharge predict subsequent mortality after pneumonia and sepsis. Am J Respir Crit Care Med 2008;177:1242-1247.

86 Sharshar T, Bastuji-Garin S, Polito A, De Jonghe B, Stevens RD, Maxime V, Rodriguez P, Cerf C, Outin H, Touraine P, et al.; Groupe de Réflexion et d'Etude des Neuromyopathies En Réanimation. Hormonal status in protracted critical illness and in-hospital mortality. Crit Care 2011;15:R47.

87 Fritz S, Lusardi M. White paper: "walking speed: the sixth vital sign". $J$ Geriatr Phys Ther 2009;32:46-49.

88 Makary MA, Segev DL, Pronovost PJ, Syin D, Bandeen-Roche K, Patel P, Takenaga R, Devgan L, Holzmueller CG, Tian J, et al. Frailty as a predictor of surgical outcomes in older patients. J Am Coll Surg 2010;210:901-908.

89 Lee DH, Buth KJ, Martin BJ, Yip AM, Hirsch GM. Frail patients are at increased risk for mortality and prolonged institutional care after cardiac surgery. Circulation 2010;121:973-978.

90 Sündermann SH, Dademasch A, Seifert B, Rodriguez Cetina Biefer H, Emmert MY, Walther T, Jacobs S, Mohr FW, Falk V, Starck CT. Frailty is a predictor of short- and mid-term mortality after elective cardiac surgery independently of age. Interact Cardiovasc Thorac Surg 2014;18:580-585.

91 Sündermann S, Dademasch A, Praetorius J, Kempfert J, Dewey T, Falk V, Mohr FW, Walther T. Comprehensive assessment of frailty for elderly high-risk patients undergoing cardiac surgery. Eur $J$ Cardiothorac Surg 2011;39:33-37.

92 McAdams-DeMarco MA, Law A, King E, Orandi B, Salter M, Gupta N, Chow E, Alachkar N, Desai N, Varadhan R, et al. Frailty and mortality in kidney transplant recipients. Am J Transplant 2015;15: 149-154.

93 Kotloff RM. Allocating organs for lung transplantation: two sides of the coin. Am J Respir Crit Care Med 2015;192:1271-1272.

94 Denehy L, Skinner EH, Edbrooke L, Haines K, Warrillow S, Hawthorne G, Gough K, Hoorn SV, Morris ME, Berney S. Exercise rehabilitation for patients with critical illness: a randomized controlled trial with 12 months of follow-up. Crit Care 2013;17:R156.

95 Walsh TS, Salisbury LG, Merriweather JL, Boyd JA, Griffith DM, Huby G, Kean S, Mackenzie SJ, Krishan A, Lewis SC, et al.; RECOVER Investigators. Increased hospital-based physical rehabilitation and information provision after intensive care unit discharge: the RECOVER randomized clinical trial. JAMA Intern Med 2015;175: 901-910.
96 Moss M, Nordon-Craft A, Malone D, Van Pelt D, Frankel SK, Warner ML, Kriekels W, McNulty M, Fairclough DL, Schenkman M. A randomized trial of an intensive physical therapy program for patients with acute respiratory failure. Am J Respir Crit Care Med 2016;193:1101-1110.

97 Puthucheary ZA, Denehy L. Exercise interventions in critical illness survivors: understanding inclusion and stratification criteria. Am J Respir Crit Care Med 2015;191:1464-1467.

98 Abizanda P, López MD, García VP, Estrella JdeD, da Silva González Á, Vilardell NB, Torres KA. Effects of an oral nutritional supplementation plus physical exercise intervention on the physical function, nutritional status, and quality of life in frail institutionalized older adults: the ACTIVNES study. J Am Med Dir Assoc 2015;16: 439.e9-439.e16.

99 Fragala MS, Dam TT, Barber V, Judge JO, Studenski SA, Cawthon PM, McLean RR, Harris TB, Ferrucci L, Guralnik JM, et al. Strength and function response to clinical interventions of older women categorized by weakness and low lean mass using classifications from the Foundation for the National Institute of Health sarcopenia project. J Gerontol A Biol Sci Med Sci 2015;70:202-209.

100 Franssen FM, Broekhuizen R, Janssen PP, Wouters EF, Schols AM. Effects of whole-body exercise training on body composition and functional capacity in normal-weight patients with COPD. Chest 2004; 125:2021-2028.

101 Puhan MA, Gimeno-Santos E, Scharplatz M, Troosters T, Walters EH, Steurer J. Pulmonary rehabilitation following exacerbations of chronic obstructive pulmonary disease. Cochrane Database Syst Rev 2011;10:CD005305.

102 Arthur HM, Daniels C, McKelvie R, Hirsh J, Rush B. Effect of a preoperative intervention on preoperative and postoperative outcomes in low-risk patients awaiting elective coronary artery bypass graft surgery: a randomized, controlled trial. Ann Intern Med 2000;133:253-262.

103 Schweickert WD, Pohlman MC, Pohlman AS, Nigos C, Pawlik AJ, Esbrook CL, Spears L, Miller M, Franczyk M, Deprizio D, et al. Early physical and occupational therapy in mechanically ventilated, critically ill patients: a randomised controlled trial. Lancet 2009;373:1874-1882.

104 Burtin C, Clerckx B, Robbeets C, Ferdinande P, Langer D, Troosters T, Hermans G, Decramer M, Gosselink R. Early exercise in critically ill patients enhances short-term functional recovery. Crit Care Med 2009:37:2499-2505.

105 Segers J, Hermans G, Bruyninckx F, Meyfroidt G, Langer D, Gosselink $R$. Feasibility of neuromuscular electrical stimulation in critically ill patients. J Crit Care 2014;29:1082-1088.

106 Kho ME, Truong AD, Zanni JM, Ciesla ND, Brower RG, Palmer JB, Needham DM. Neuromuscular electrical stimulation in mechanically ventilated patients: a randomized, sham-controlled pilot trial with blinded outcome assessment. J Crit Care 2015;30:32-39.

107 Files DC, D'Alessio FR, Johnston LF, Kesari P, Aggarwal NR, Garibald BT, Mock JR, Simmers JL, DeGorordo A, Murdoch J, et al. A critical role for muscle ring finger-1 in acute lung injury-associated skeletal muscle wasting. Am J Respir Crit Care Med 2012;185:825-834.

108 Files DC, Liu C, Pereyra A, Wang ZM, Aggarwal NR, D'Alessio FR, Garibaldi BT, Mock JR, Singer BD, Feng X, et al. Therapeutic exercise attenuates neutrophilic lung injury and skeletal muscle wasting. Sci Transl Med 2015;7:278ra32.

109 Cohen S, Nathan JA, Goldberg AL. Muscle wasting in disease: molecular mechanisms and promising therapies. Nat Rev Drug Discov 2015;14:58-74.

110 Haidet AM, Rizo L, Handy C, Umapathi P, Eagle A, Shilling C, Boue D, Martin PT, Sahenk Z, Mendell JR, et al. Long-term enhancement of skeletal muscle mass and strength by single gene administration of myostatin inhibitors. Proc Natl Acad Sci USA 2008;105:4318-4322.

111 Casaer MP, Mesotten D, Hermans G, Wouters PJ, Schetz M, Meyfroidt G, Van Cromphaut S, Ingels C, Meersseman P, Muller J, et al. Early versus late parenteral nutrition in critically ill adults. $N$ Engl J Med 2011;365:506-517.

112 Doig GS, Simpson F, Sweetman EA, Finfer SR, Cooper DJ, Heighes PT, Davies AR, O'Leary M, Solano T, Peake S; Early PN Investigators of the ANZICS Clinical Trials Group. Early parenteral nutrition in critically ill patients with short-term relative 
contraindications to early enteral nutrition: a randomized controlled trial. JAMA 2013;309:2130-2138.

113 Needham DM, Dinglas VD, Bienvenu OJ, Colantuoni E, Wozniak AW, Rice TW, Hopkins RO; NIH NHLBI ARDS Network. One year outcomes in patients with acute lung injury randomised to initial trophic or full enteral feeding: prospective follow-up of EDEN randomised trial. BMJ 2013;346:f1532.

114 Hermans G, Casaer MP, Clerckx B, Güiza F, Vanhullebusch T, Derde S, Meersseman P, Derese I, Mesotten D, Wouters PJ, et al. Effect of tolerating macronutrient deficit on the development of intensive-care unit acquired weakness: a subanalysis of the EPaNIC trial. Lancet Respir Med 2013;1:621-629.

115 Takala J, Ruokonen E, Webster NR, Nielsen MS, Zandstra DF, Vundelinckx G, Hinds CJ. Increased mortality associated with growth hormone treatment in critically ill adults. N Engl J Med 1999; 341:785-792.

116 Van den Berghe G. Novel insights into the neuroendocrinology of critical illness. Eur J Endocrinol 2000;143:1-13.

117 Schulman RC, Mechanick Jl. Metabolic and nutrition support in the chronic critical illness syndrome. Respir Care 2012;57:958-977. [Discussion, pp. 977-978.]

118 Clegg A, Young J, Illiffe S, Rikkert MO, Rockwood K. Frailty in elderly people. Lancet 2013;382:1328.

119 Kiely DK, Cupples LA, Lipsitz LA. Validation and comparison of two frailty indices: The MOBILIZE Boston Study. J Am Geriatr Soc 2009; 57:1532-1539.

120 Rockwood K, Mitnitski A, Song X, Steen B, Skoog I. Long-term risks of death and institutionalization of elderly people in relation to deficit accumulation at age 70. J Am Geriatr Soc 2006;54:975-979. 